\title{
RESEARCH NOTE \\ Diet of guanaco in sheep-free rangeland in Tierra del Fuego, Chile
}

\author{
Alejandra E. Muñoz ${ }^{1,2}$, and Javier A. Simonetti ${ }^{1}$ \\ ${ }^{1}$ Facultad de Ciencias, Universidad de Chile. Casilla 653, Santiago, Chile. \\ ${ }^{2}$ Departamento de Ecosistemas y Medio Ambiente, Facultad de Agronomía e Ingeniería Forestal, Pontificia \\ Universidad Católica de Chile. Vicuña Mackenna 4860, Macul, Santiago, Chile.
}

\begin{abstract}
A.E. Muñoz, and J.A. Simonetti. 2013. Diet of guanaco in sheep-free rangeland in Tierra del Fuego, Chile. Cien. Inv. Agr. 40(1):185-191. Guanaco (Lama guanicoe), the only native ungulate of Tierra del Fuego, uses the forests more extensively after the introduction of sheep. It is presumed that the regeneration of lenga (Nothofagus pumilio) is hampered by guanaco browsing. In this context, the diet of guanaco in Tierra del Fuego was evaluated through a microhistological analysis of feces in a livestock-free area dominated by lenga forest. Guanacos behaved largely as herbivorous grazers and exhibited seasonal variations in their grazing habits. Compared to other studies in Tierra del Fuego, which were conducted in areas where sheep and guanaco grazed together, we reported that the guanacos avoided and consumed fewer trees. These results have management implications, as the proper management of livestock could reduce the potential effects of the guanacos upon the lenga forests.
\end{abstract}

Key words: Lama guanicoe, Nothofagus pumilio, feeding habits, microhistological analysis.

\section{Introduction}

Guanaco (Lama guanicoe), a widely distributed camelid in South America, is a generalist herbivore. Largely a grazer, guanacos also feed upon tree and shrub foliage and even lichens, depending on availability (Raedeke and Simonetti, 1988; Puig et al., 2001; Puig et al., 2011). On Tierra del Fuego Island, at the southernmost tip of its distribution, guanacos have faced competition with sheep (Ovies aries) since the second half of the 19th century. In the presence of sheep, guanacos use the forest more extensively than

Received March 9, 2012. Accepted November 28, 2012. Corresponding author: aemunoz@uc.cl they would otherwise (Raedeke, 1982). This habitat shift might also account for the increased consumption of woody plants. In the absence of sheep, guanacos are mainly grazers but become browsers when pushed into the forests by sheep (Raedeke, 1979).

Recently, sheep have been removed from Vicuña, Tierra del Fuego. Therefore, free from the competition of sheep, guanacos ought to behave as grazers, with a lower consumption of tree and shrub foliage than in the past. This potential diet change in guanacos has managerial implications. The recruitment and growth of lenga (Nothofagus pumilio), the main timber of southern Chile and Argentina, is presumed to be hampered by guanaco 
browsing (Martínez-Pastur et al., 1999; Pulido et al., 2000). If guanacos were impinging upon lenga recruitment due to a competition-induced diet shift, then in the absence of sheep, forest regeneration ought to be released from such herbivore pressure. In this note, we analyzed the diet of a guanaco population in Tierra del Fuego from areas without sheep and compared it with historical records from areas where guanacos and sheep grazed sympatrically.

\section{Materials and methods}

The study was performed at Karukinka, Vicuña, Tierra del Fuego $\left(54^{\circ} 11^{\prime} \mathrm{S}, 68^{\circ} 45^{\prime} \mathrm{W}\right)$, in a privately protected area owned by the Wildlife Conservation Society from which sheep were removed approximately 10 years ago. The landscape is dominated by lenga forests intermingled with Patagonian steppe and wetlands. At the sampling sites, most of the forests had been partially logged prior to becoming a protected area.

Guanaco diet was assessed through microhistological analysis of feces. Samples from 37 individuals were collected from November 2006 (austral spring, eight samples), January 2007 (summer, nine samples), April 2007 (fall, 10 samples) and July 2007 (winter, 10 samples). Samples were fresh feces from dung piles or single depositions, belonging to single individuals. Plant composition was determined from epidermal tissue at the Laboratorio de Microhistología, Instituto Nacional de Tecnología Agropecuaria (INTA), Bariloche (Argentina). Plant species were classified as grass, grass-like (Cyperaceae and Juncaceae families), shrubs, trees, forbs, hemiparasites and mosses. Plant species diversity was estimated through the Shannon index. Differences in diversity between seasons were assessed through an Analysis of Variance and the a posteriori Holm-Sidak test. Differences in species richness were evaluated through KruskalWallis Analysis of Variance and the a posteriori Dunn test (Zar, 2010).
During the summer of 2007 , vegetation was surveyed from a study area consisting of 30 parcels of land following the methodology of "Carta de Ocupación de Tierras" (Ettiene and Prado, 1982), from which the relative frequency of herbaceous (grass, grass-like and forbs), shrubs and trees was obtained. Considering relative environmental availability and consumption, dietary preference of these plant groups during summer was evaluated using the electivity index of Ivlev (E), which has been used in other studies of the guanaco diet (Raedeke, 1982; Puig et al., 1996). Based on Puig et al. (1996), a value of -0.3 to +0.3 was accepted as limits for the indifference rank.

\section{Results}

On a yearly basis, guanaco diet was comprised of 43 species of vascular plants and one moss species (Sphagnum sp.). The category Nothofagus spp. corresponds to the sum of lenga and ñirre $(N$. antarctica) because it was impossible to further discriminate between the two (Table 1). Species richness varied seasonally $\left(\mathrm{H}_{3}=12, \mathrm{P} \leq 0.01\right)$. The number of species consumed during the winter (13.9 \pm 0.5 species consumed per individual; mean \pm standard error) was significantly lower than the consumption during the fall $(16.8 \pm 0.4 ; \mathrm{Q}=3.4$, $\mathrm{P} \leq 0.05)$, but exhibited no significant differences from the summer $(15.4 \pm 0.7)$ or the spring (15.8 \pm 0.6 ). Diet diversity was significantly lower during the winter $\left(\mathrm{H}^{\prime}=2.1 \pm 0.1\right)$ compared to other seasons (summer: $2.3 \pm 0$, fall: $2.4 \pm 0$ and spring: $2.4 \pm 0 ; \mathrm{F}_{3,33}=10.3, \mathrm{P} \leq 0.01$; a posteriori $\mathrm{P} \leq 0.01$ for comparisons between winter and any other season, $\mathrm{P}_{0.05}=0.01$ for all comparisons).

Grasses were the main component of the diet (29.3 $\pm 3.2 \%$ of feces content), and two grass species (Alopecurus magellanicus and Poa sp.) were also among the most frequent species found in the diet. Forbs $(17 \pm 4.6 \%)$, shrubs $(16.7 \pm 2.8 \%)$ and grass-like plants $(16.1 \pm 2.6 \%)$ had similar importance and were the next most consumed items. Trees accounted for $14.9 \% \pm 2.9$. Of these, 
Table 1. Guanaco diet composition (average (median)) by season in Vicuña, Tierra del Fuego.

\begin{tabular}{|c|c|c|c|c|c|}
\hline \multirow[b]{3}{*}{ Life form species } & \multicolumn{4}{|c|}{ Season } & \multirow[b]{3}{*}{ Annua } \\
\hline & Spring & Summer & Fall & Winter & \\
\hline & $(\mathrm{n}=8)$ & $(n=9)$ & $(\mathrm{n}=10)$ & $(\mathrm{n}=10)$ & \\
\hline \multicolumn{6}{|l|}{ Grass species } \\
\hline Alopecurus magellanicus & $11.2(11.4)$ & $7.8(6.7)$ & $10.8(10.2)$ & $9(8.5)$ & 9.7 \\
\hline Bromus sp. & $0.2(0)$ & & $0.2(0)$ & & 0.1 \\
\hline Festuca gracilima & & & & $6.8(1.4)$ & 1.9 \\
\hline Holcus lanatus & $0.6(0.3)$ & & $0.1(0)$ & & 11.2 \\
\hline Poa sp. & $10.3(11.2)$ & $16.4(16.3)$ & $18.3(17.4)$ & $21.4(20.9)$ & 5.5 \\
\hline Stipa sp. & $0.5(0)$ & & $0.1(0)$ & & 0.9 \\
\hline Trisetum sp. & $1(0.9)$ & $0.9(0)$ & $1.5(0.7)$ & $0.5(0)$ & 0.1 \\
\hline \multicolumn{6}{|l|}{ Grass-like species } \\
\hline Carex sp. & $14.4(14.8)$ & $13.1(13.9)$ & $12.8(11.4)$ & $6.9(6.7)$ & 11.8 \\
\hline Eleocharis sp. & $0.9(0)$ & $3.7(2.5)$ & $1.6(1.6)$ & $0.3(0)$ & 1.6 \\
\hline Luzula chilensis & $0.5(0)$ & $4.6(3.1)$ & $2.5(2.5)$ & $1.8(0.9)$ & 2.4 \\
\hline Marsippospermum grandiflorum & $1.3(1.1)$ & & & & 0.3 \\
\hline \multicolumn{6}{|l|}{ Shrub species } \\
\hline Baccharis magellanica & $1.9(0)$ & & & & 0.5 \\
\hline Berberis sp. & $4.3(3.1)$ & $2(1.2)$ & $4.7(5)$ & $7.4(7.1)$ & 4.6 \\
\hline Chillotrichum diffusum & $9.2(9.3)$ & $0.4(0)$ & $<0.1(0)$ & & 2.4 \\
\hline Empetrum rubrum & $4.1(3.5)$ & $6.2(4.1)$ & $13.1(13.6)$ & $10.2(10.9)$ & 8.4 \\
\hline Senecio alloeophyllus & & & & $2.5(2.7)$ & 0.6 \\
\hline Non identified shrub & & & $0.2(0)$ & $<0.1(0)$ & 0.1 \\
\hline \multicolumn{6}{|l|}{ Tree species } \\
\hline Maytenus sp. & $0.3(0)$ & & & & 0.1 \\
\hline Nothofagus betuloides & & & & $22.4(23.8)$ & 5.6 \\
\hline Nothofagus spp. ${ }^{1}$ & $13.4(13.6)$ & $15.2(15)$ & $8.4(9.1)$ & & 9.2 \\
\hline \multicolumn{6}{|l|}{ Forb species } \\
\hline Acaena sp. & & $1.2(0)$ & $0.3(0)$ & & 0.4 \\
\hline Achillea millefolium & $0.3(0)$ & & & & 0.1 \\
\hline Arjona patagonica & & & & $0.1(0)$ & 0 \\
\hline Asteraceae species & $2.1(0.3)$ & $0.7(0)$ & $0.4(0)$ & $<0.1(0)$ & 0.8 \\
\hline Blechnum penna-marina & & $0.8(0)$ & $1(0.3)$ & $1.6(1.4)$ & 0.9 \\
\hline Callitriche sp. & & $0.7(0)$ & $<0.1(0)$ & & 0.2 \\
\hline Capsella bursa-pastoris & & $0.2(0)$ & $0.2(0)$ & & 0.1 \\
\hline Cerastium arvense & $1.3(1)$ & $1.5(1.1)$ & $1.6(1.5)$ & $0.5(0)$ & 1.2 \\
\hline Cotula scariosa & & $0.4(0)$ & $0.4(0)$ & $<0.1(0)$ & 0.2 \\
\hline Erodium cicutarium & $0.5(0)$ & & & & 0.1 \\
\hline Gunnera magellanica & $3.7(3.7)$ & $8.2(8.1)$ & $4.2(4.1)$ & $0.9(0.4)$ & 4.3 \\
\hline Osmorhiza sp. & $2.3(2)$ & $0.5(0)$ & $0.2(0)$ & $0.1(0)$ & 0.8 \\
\hline Plantago sp. & & & $0.1(0)$ & & 0 \\
\hline Ranunculaceae species & & & & $0.1(0)$ & 0 \\
\hline Ranunculus sp. & & $2.6(0.9)$ & $2.4(2)$ & & 1.3 \\
\hline Rosaceae species & & & & $0.5(0)$ & 0.1 \\
\hline
\end{tabular}


Continuation to Table 1.

\begin{tabular}{|c|c|c|c|c|c|}
\hline \multirow[b]{3}{*}{ Life form species } & \multicolumn{4}{|c|}{ Season } & \multirow[b]{3}{*}{ Annual } \\
\hline & Spring & Summer & Fall & Winter & \\
\hline & $(\mathrm{n}=8)$ & $(\mathrm{n}=9)$ & $(\mathrm{n}=10)$ & $(\mathrm{n}=10)$ & \\
\hline Rubus geoides & $11.6(11.9)$ & $5.9(6.3)$ & $6.2(6.7)$ & $0.7(0)$ & 6.1 \\
\hline Rumex sp. & & $0.4(0)$ & $0.3(0)$ & $0.1(0)$ & 0.2 \\
\hline Veronica serphyllifolia & & & $0.2(0)$ & & 0 \\
\hline Viola sp. & & $0.7(0)$ & $0.1(0)$ & & 0.2 \\
\hline Non identified forb & $0.5(0)$ & $0.2(0)$ & $<0.1(0)$ & & 0.2 \\
\hline Non identified fruit & & $0.3(0)$ & & & 0.1 \\
\hline \multicolumn{6}{|l|}{ Hemiparasite species } \\
\hline Misodendrum sp. & $1.7(1)$ & $4.5(3.8)$ & $7.2(6.5)$ & $4.3(3.8)$ & 4.4 \\
\hline \multicolumn{6}{|l|}{ Moss species } \\
\hline Sphagnum sp. & $2.2(2)$ & $1(0.5)$ & $0.9(0.6)$ & $2(0.7)$ & 1.5 \\
\hline
\end{tabular}

${ }^{1}$ Sum of Nothofagus pumilio and Nothofagus Antarctica.

lenga and ñirre beech, accounted for $9.2 \pm 3.4 \%$ of the guanaco diet, with a peak of $15.2 \%$ in the summer and no consumption during the winter. Hemiparasites and mosses were the least represented life-forms in the diet with $4.4 \pm 1.1 \%$ and $1.5 \pm$ $0.3 \%$, respectively (Figure 1 ).

Monocotyledonous consumption was rather homogeneous during the year, but consumption of grasses increased from $23.7 \%$ during the spring to a peak of $37.5 \%$ in the winter. Shrubs, trees and forbs showed greater variability throughout the year, and the contribution of woody plants (shrubs + trees) and forbs were approximately complementary. Both shrubs and trees were consumed during the year, but the species composition changed. Among shrubs, Empetrum rubrum was the greatest contributor to the diet throughout the year. With regard to trees, from the spring to the fall, guanaco fed largely on lenga and ñirre, and in winter, the guanacos fed on magellanic beech (Nothofagus betuloides), which was also the main component of the winter diet $(22.4 \%)$, closely followed by Poa sp. (21.4\%). Forbs were mostly consumed in the spring (22.2\%) and the summer $(24.3 \%)$, while consumption in the winter fell to $4 \%$. With respect to dietary preference during the summer, herbaceous plants (forbs and monocotyledonous) were preferred $(E=0.4)$, while shrub and tree consumption were avoided $(\mathrm{E}=-0.5$ in each one).

\section{Discussion}

Guanacos in Vicuña, in south central Tierra del Fuego, behaved as a generalist herbivore, as in other areas of its distribution (Raedeke and Simonetti, 1988; Puig et al., 1996; Ortega and Franklin, 1988; Baldi et al., 2001). The most consumed species of trees, shrubs and forbs are also the dominant species in lenga forests, while the most frequently consumed monocotyledoneous plants are the dominant species in open areas (Moore, 1983). Guanacos also exhibited the described dietary flexibility, which allows them to seasonally alternate between grazing and browsing habits (Puig et al., 1996; Puig et al., 2001; Baldi et al., 2004). For almost the entire year, the guanacos were mainly herbivorous grazers, consuming grasses, grass-like plants and forbs. During the winter, however, when much of the vegetation 


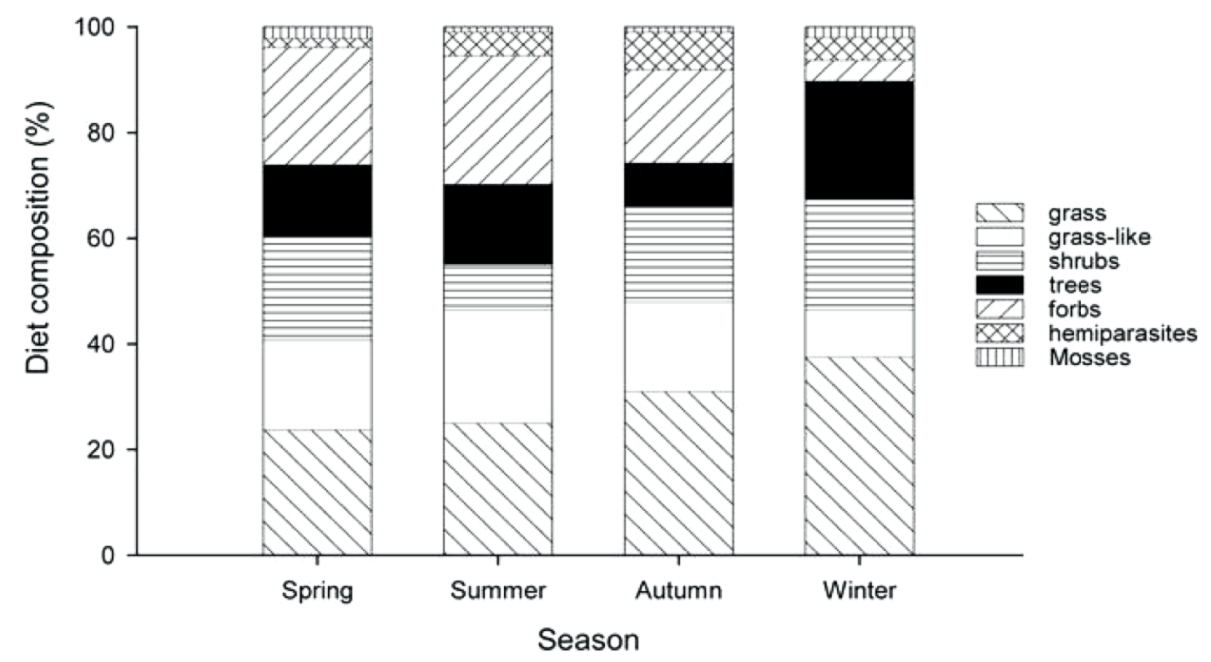

Figure 1. Seasonal guanaco diet in Vicuña (Tierra del Fuego, Chile) according to life form of plants, based on fecal samples $(n=37)$.

is covered with snow and the availability of herbaceous plants is scarce, guanacos change their habits by increasing their reliance upon woody species (Bahamonde et al., 1986; Puig et al., 1996). The reduced winter availability of vegetation could explain why their winter diet is less diverse, similar to other guanaco populations in the high Andes of Central Argentina (Puig et al., 2011). Reliance upon on $N$. betuloides in the winter is likely due to the fact that this plant species is an evergreen with foliage available above snow level, while the lack of consumption of lenga and ñirre in winter could be explained by the fact that these species are deciduous, and guanacos only feed on the leaves and sprouts of Nothofagus (Martínez-Pastur et al., 1999; Pulido et al., 2000).

Compared to guanacos in the central region of the island, guanacos in Vicuña consume fewer grasses and more woody plants year-round (Raedeke, 1980; Bonino and Pelliza, 1991). The comparative low consumption of grasses might be because there is also a comparatively smaller proportion of steppe (where grasses are abundant) compared to the central part of the island. However, among woody species, the guanacos in Vicuña exhibited a lower but similar consumption of Nothofagus
(14.9\% annual average) than the guanacos in the forest-steppe transition regions (19\% annual average; Bonino and Pelliza, 1991). Moreover, the occurrence of lenga + ñirre in the guanaco diet was significantly lower in Vicuña $(72.97 \%$; $\mathrm{n}=37)$ compared to $100 \%(\mathrm{n}=24)$ reported by Raedeke (1980) $(\mathrm{z}=2.43 ; \mathrm{P} \leq 0.01)$ in an area with a lower availability of forests but where sheep were also grazing. In Vicuña, where sheep have been removed, the avoidance of woody plants (tree + shrub) consumption is greater $(E=-0.5)$ compared to almost no avoidance ( $\mathrm{E}=-0.32$ ), as reported by Radeke (1980). In another study from Tierra del Fuego in an area near Vicuña (c.a. 60 $\mathrm{km}$ ) with a similar landscape but where cattle and sheep were also grazing, guanacos consumed $21.8 \%$ lenga + ñirre year-round (Soler Esteban et al., 2012) compared to the $9.23 \%$ reported in Vicuña; the consumption of grasses was similar in both cases. Therefore, these results support the hypothesis that removing sheep would imply a lower tree consumption, even when considering the abundance of logged forests of lenga in the study area, which offer a greater opportunity for regeneration and where the number of guanaco browsing on lenga is higher compared to unlogged forests (Martínez-Pastur et al., 1999; Muñoz, 2008). 
Analyzing the resource use of native ungulates and the potential effect of livestock competition is important for species management and conservation (Soler Esteban et al., 2012). Our result suggests that the putative negative impact of guanacos upon the lengas is a result of the presence of sheep. Therefore, proper management of sheep stock in Tierra del Fuego seems a feasible option to reduce the potential effects of guanacos upon the lenga forests.

\section{Acknowledgments}

We are grateful to the Wildlife Conservation Society for their financial and logistical support of this study. We thank Laura Borrelli (INTA-Bariloche) for the analysis of feces and Melica Muñoz for her assistance with plant species recognition. We also acknowledge helpful comments and suggestions from Benito González.

\title{
Resumen
}

\begin{abstract}
A.E. Muñoz y J.A. Simonetti. 2013. Dieta del guanaco en ambientes libres de ganado ovino en Tierra del Fuego, Chile. Cien. Inv. Agr. 40(1):185-191. El guanaco (Lama guanicoe), el único ungulado nativo de Tierra del Fuego, posterior a la introducción de ovejas utiliza mayormente el bosque. La regeneración de la lenga (Nothofagus pumilio) se presume ser obstaculizada por el ramoneo de guanacos. En este contexto se evaluó la dieta del guanaco en Tierra del Fuego mediante análisis microhistológico de fecas en un área libre de ganado dominada por bosques de lenga. El guanaco se comportó como un herbívoro generalista, exhibiendo variaciones estacionales. En comparación con otros estudios en Tierra del Fuego en simpatría con ovejas, se reportó menor consumo y rechazo de árboles. Estos resultados tienen implicancias en gestión, ya que un manejo apropiado del ganado podría reducir el potencial impacto de los guanacos sobre los bosques de lenga.
\end{abstract}

Palabras clave: Lama guanicoe, Nothofagus pumilio, hábitos de consumo, análisis microhistológico.

\section{References}

Bahamonde, N., S. Martin, and A. Pelliza Sbriller. 1986. Diet of guanaco and red deer in Neuquen Province Argentina. Journal of Range Management 39:22-24.

Baldi, R., S.D. Albon, and D.A. Elston. 2001. Guanacos and sheep: evidence for continuing competition in arid Patagonia. Oecologia 129:561-570.

Baldi, R., A. Pelliza-Sbriller, D. Lestón, and S. Albon. 2004. High potential for competition between guanacos and sheep in Patagonia. Journal of Wildlife Management 68:924-938.

Bonino, N., and A. Pelliza. 1991. Composición botánica de la dieta del guanaco (Lama guanicoe) en dos ambientes contrastantes de Tierra del Fuego, Argentina. Ecología Austral 1:97-102.

Etienne, M., and C. Prado. 1982. Descripción de la vegetación mediante la cartografía de ocupación de tierras. Ciencias Agrícolas Nº10, Universidad de Chile, Santiago, Chile. 120 pp.

Martínez-Pastur, G., P.L. Peri, M.C. Fernández, G. Staffieri, and D. Rodríguez. 1999. Desarrollo de la regeneración a lo largo del ciclo del manejo forestal de un bosque de Nothofagus pumilo:2. Incidencia del ramoneo de Lama guanicoe. Bosque 20:47-53.

Moore, D.M. 1983. Flora of Tierra del Fuego. Anthony Nelson, England, Missouri Botanical Garden, USA. 369 pp. 
Muñoz, A.E. 2008. Guanaco (Lama guanicoe) browsing on lenga (Nothofagus pumilio) regeneration in Tierra del Fuego. Tesis de Magíster, Facultad de Ciencias, Universidad de Chile. Santiago, Chile. 31 pp.

Ortega, I.M., and W.L. Franklin. 1988. Feeding habitat utilization and preference by guanaco male groups in the Chilean Patagonia. Revista Chilena de Historia Natural 61:209-216.

Puig, S., F. Videla, S. Monge, and V. Roig. 1996. Seasonal variations in guanaco diet (Lama guanicoe Müller 1776) and food availability in northern Patagonia, Argentina. Journal of Arid Environments 34:215-224.

Puig, S., F. Videla, M.I. Cona, and S. Monge. 2001. Use of food availability by guanacos (Lama guanicoe) and livestock in Northern Patagonia (Mendoza, Argentina). Journal of Arid Environments 47:291-308.

Puig, S., M.I. Rosi, F. Videla, and E. Méndez. 2011. Summer and winter diet of the guanaco and food availability for a High Andean migratory population (Mendoza, Argentina). Mammalian Biology 76:727-734.

Pulido, F.J., B. Díaz, and G. Martínez-Pastur. 2000. Incidencia del ramoneo del guanaco (Lama guanicoe Müller) sobre la regeneración temprana en bosques de lenga (Nothofagus pumilio (Poepp. et End1.) Krasser) de Tierra del Fuego, Argentina. Investigación Agraria: Sistema de Recursos Forestales 9:381-394.

Raedeke, K., 1979. Population dynamics and socioecology of the guanaco (Lama guanicoe) in Magallanes, Chile. PhD Thesis. University of Washington, Seattle. 409 pp.

Raedeke, K.J. 1980. Food habits of the guanaco (Lama guanicoe) of Tierra del Fuego, Chile. Turrialba 30:177-181.

Raedeke, K.J. 1982. Habitat use by guanacos (Lama guanicoe) and sheep on common range, Tierra del Fuego, Chile. Turrialba 32:309-314.

Raedeke, K., and J.A. Simonetti. 1988. Food habits of Lama guanicoe in the Atacama desert in northern Chile. Journal of Mammalogy 69:198-201.

Soler Esteban, R., G. Martínez Pastur, M.V.Lencinas, and L. Borrelli. 2012. Differential forage use between large native and domestic herbivores in Southern Patagonian Nothofagus forests. Agroforestry Systems 85:397-409.

Zar, J.H. 2010. Biostatiscal Analysis (5 ${ }^{\text {th }}$ Ed.). Pearson, U.S.A. 944 pp. 
